\title{
The Role of Art Re-Defined in the selected Post-Modern Novels
}

\section{* Prof. Balakrishna $\mathrm{H}$}

Art, one might easily surmise, has a history as old as human civilization. Although art depends largely on one's personal perspective, it has also led to the birth of many schools of thought and practice. So to say, it is a product of a particular social and cultural milieu. Art is such an integral part of our everyday life that it can take any form or content.

India has a rich cultural heritage having existed for many centuries. It consists of various art forms such as Sangetha, Nrithya, Natya, Nataka, Shilpashastra and others. Marga and Desi forms multiply the number of those art forms. There are thousands of internationally celebrated artists in these art forms. There is a well-organized and established art and aesthetic theories in India. Both Governmental and Non-Governmental Organizations are working hard to preserve and promote Indian Culture. Art in India has got aesthetic, religious, cultural, social, even economic dimension. All in all, Indian Arts is in a vibrant form now. Surely, it won't be an exaggeration if one said that Art has emerged as one of the major strands and guiding forces of life in India.

It is an acknowledged fact that the creative writings reflect the mores and experiences of contemporary life. 'It is true that the artist draws his sustenance from the society he lives in, but it is equally true that he breathes new life into it, invigorates it and renders the drab life a shade better than he found it', Dr. C.D. Narasimhaiah observes. When this is the fact, we do not get proportionate number of Indian creative writings, which discuss the rich cultural heritage of India as their major theme. An interesting thing here is, when we talk about writers on art, they too belong to the class of artists. Their works on art become their impressions of another form of art. It could be perceived as one form of art reacting to another form of art, leading to the synthesis and a new holistic experience. This harmony between

*HOD, Department of English, Vivekananda College, Puttur 
two different forms of art would certainly enrich the experience of the readers, if handled effectively by the artists, here the writers. Actually Indian Literature has tried to capture the wealth of our culture and art in various languages. But the question is how effectively have the Indian writers and critics utilized this rich cultural heritage in their creative works? Even though India has the vibrant cultural ambience, still it remains a puzzle that art-fictions are rarely discussed from the perspectives of art and culture.

In this paper an attempt is made to reconsider the concerns of art as reflected in the selected four Indian novels. The four Novels are

\section{R.K. Narayan's The Guide [1958]}

2.Anita Nair's Mistress [2005]

3. Jalapatha [1967]-A novel in Kannada by S. L. Bhairappa

4.Mandra [2002]-Anovel in Kannada by S. L. Bhairappa

For Rosie, in The Guide art is an identity to her and she enjoys the company of artists and respects them. For Raju the art in Rosie is a business prospect. Rosie has only limited role as an artist in the novel. The paragraphs that describe the serpent dance are dexterously rendered. We get only the glimpses of an artist's life and art jargons here. In this novel the concept of art is brought out only functionally to serve the overall plot of the novel.

In Anita Nair's novel Mistress, we get the better portrayal of the artistic concerns. The nine chapters are named after nine Rasaas, namely - Sringaram, Hasyam, Karunam, Raudram, Veeram, Bhayanakam, Beebathsam, Adbhutham and Shantham. The novel depicts the art of Kathakkali as a way of life. The same becomes the end of life also to the Kathakkali artist Koman and his Guru Ashan. It is his passion that matures him as an artist. To Shyam the same art is nothing but mere waste of time and at the most it can earn money in his hotel business. It is this juxtaposing of two attitudes towards art that enables the novel to present a serious discourse on art. The artist in the novelist also contributed a lot in sequencing and narrating the story in an artistic way -through Navarasas. The thematic concerns such as - the conflicts between the artist and man, the artistic and 
commercial concerns, the art and life, bring a different dimension to the discussion of art in the novel Mistress. The Puranic stories(Nala-Bahuka) are used as the backdrop of the novel and we witness various characters enacting various roles to exhibit various emotions or passions. Thus the artistic integrity between the theme and the structure has made this novel to attain a special niche in the post-colonial Indian writing.

In Jalapath, a novel in Kannada, Sri S. L. Bhairappa presents the turmoils of an artist in an urban environment in the realistic sense. Sripathi alias Bhupathi, (symbolic name) a painter having a very good artistic sensibility works for an advertising agency in Mumbai. Soon he realises the fact that the proficiency of an artist is missing in his paintings. With the help of his wife Vasubdhara, alias Bhudevi(yet another symbolic name), the artist attains the satisfaction level of creative art. But soon after this achievement he rejects the urban life that supported his livelihood and goes to rural setting to cater the needs of an artist for creativity. Unfortunately he fails to meet the demands of even a humble life there and returns to the barren city again. The whole novel is rendered from two points of views, shifting between Sripathi and Vasundhara. The paragraphs, where the artist in Sripathi creates his creation, ie, painting, in Khandala and Bhudevi is pregnant or another form of creation of life, could be considered as the best part in the novel. The novel raises many questions related to art and life, artist and his surroundings. Thus the post colonial novel Jalapatha tries to redefine the concerns of art and artist in a modern, urbanizing society.

In S. L. Bhyrappa's Mandra, another Kannada novel, the theme of art and art related issues touch different depth, hitherto unknown. Here we get the picture of the contradictions between the personality of an artist and individual. The protagonist Mohan Lal is in the height of fame as a celebrated vocalist/musician. He could attract thousands of audience and hold their rapt attention also. But in his personal life, he falls into such an ignominy that the artist is almost forgotten. He rationalises that the artist in him is in need of newer and newer experiences and gradually it turns to be mania of physical desire. In 
the name of art, he fulfils his personal desire and for which art takes a kind of poetic justice at the end. He remains all alone as an artist at the end of his musical journey whereas other artists enjoy their musical journey with their dearly loved disciples. As a foil to this character, we have Mohan Lal's guru, a saint, whose music considered to be dull by Mohan Lal. The novel raises many questions pertaining to art, artist and the role of these two in the society; artist's desire to create something new, anxieties that an artist faces, etc. Throughout the novel the imageries used complement the thematic concerns of the novel. The novel presents rather ironically the attempts of an artist to excel as an artist even at the cost of his morals in his personal life. Undoubtedly Mandra could be acclaimed as the best novel in the post colonial context that exploits art and its concerns to its supreme level. The harmony between the form and content, between languageimages and theme, help the readers to discover the depth(Mandra) of an artistic experience and also wonder about the rift or turmoil that take place in the depth of an artist.

To trace the transition in the post colonial art-related Indian novels, it could noted that R. K Narayan's The Guide which was published in 1958 , art is only a sub-plot and we get only a superficial glimpse of art. In Anita Nair's Mistress, which was published in 2005, we get a better understanding of art and art related concerns. The novel, even in its structure, is artistic. Thus it shows higher level of integration in its artistic concerns both in its theme and structure. S. L. Bhairappa's novel Jalapatha, published in 1967, in its own way presents the anxieties of an artist in a changing social milieu effectively. The design of an artist and the design of life overlap here that provides the better understanding of art. The philosophy of art and life, and their mutual understanding find their supreme expression in S. L. Bhairappa's novel Mandra, which was published in 2002. The novel, indeed, extends the experience of art to an intuitive level. Certainly art has gained a lot in the hands of S. L. Bhairappa. Thus it could be said confidently that art has created its own place in the post colonial era of Indian novels. 


\section{Works Cited:}

Narayan, R.K. The Guide. Mysore: Indian Thought Publications, 1958.

Nair, Anita. Mistress. New Delhi: Penguin Books, 2005.

Bhairappa, S. L. Jalapath. Bengaluru:Sahithya Bhandara, 1967.

Bhairappa, S. L. Mandra. Bengaluru:Sahithya Bhandara, 2002.

Naik M.K. (ed.) Aspects of Indian Writing in English, Essays in Honor of

Professor K.R. Srinivasa Iyengar. New Delhi: The Macmillan, 1979. 